УДК 376:004.9:159.93:378.046.4

Оксана Бавольська, ORCID iD 0000-0002-9740-9384 доктор філософії в галузі освіти, методист обласного ресурсного цеентру із підтримки інклюзивної освіти Миколаївський обласний інститут післядипломної педагогічної освіти вул. Наваринська, 6, 54030, Миколаїв, Украӥна oksana.bavolska@moippo.mk.ua

Андрій Васильєв, ORCID iD 0000-0003-3430-3758 засновник Briolight, кандидат економічних наук, доиент кафедри фінансів і кредиту Чорноморський національний університет імені Петра Могили вул. 68 Десантників, 10, 54000, Миколаїв, Украӥна brio@briolight.com

\title{
КОРЕКЦІЯ ПСИХОФІЗИЧНОГО РОЗВИТКУ ДІТЕЙ ІЗ ОСОБЛИВИМИ ОСВІТНІМИ ПОТРЕБАМИ ЗАСОБАМИ ДОПОВНЕНОЇ РЕАЛЬНОСТІ IНТЕРАКТИВНОЇ ПЛАТФОРМИ ВRIOLIGНT
}

У статті висвітлено застосування інструментів інтерактивної платформи Briolight як ефективного засобу корекиії порушень психофізичного розвитку дітей із особливими освітніми потребами. Застосування інтерактивних інструментів Briolight трунтується на положеннях комплексного залучення провідних аналізаторів.

Визначено основні характеристики інструментів та зміст означеної технології. Розкрито особливості використання таких інструментів інтерактивної платформи Briolight: інтерактивна підлога, інтерактивна стіна, інтерактивна пісочниця, інтерактивна панель, комплекс розвитку великої моторики, комплекс розвитку дрібної моторики, інтерактивне логопедичне дзеркало, інтерактивний метроном, інтерактивні гіроскопи тощз. Обгрунтовано доречність застосування інструментів інтерактивної платформи Briolight у корекційно-розвитковій роботі з дітьми, які мають порушення психофізичного розвитку. Окреслено функиї педагога, який застосовує иџю технологію в корекційно-розвитковій роботі.

Означено перспективи в поглибленому й докладному дослідженні ефективності застосування названого інструменту під час підвищення кваліфікащії педагогічних працівників закладів освіти та інклюзивно-ресурсних цеентрів.

Ключові слова: діти з особливими освітніми потребами; інтерактивна платформа Briolight; корекція розвитку; сенсорна інтеграція.

(C) Бавольська О. В., Васильєв А. А., 2021

Вступ. Ключовою умовою успішного всебічного розвитку дитини $є$ їі повноцінний сенсорний поступ, тобто гармонійний розвиток процесів сприйняття та формування уявлень про предмети і явища навколишнього світу, що відбуваються внаслідок роботи аналізаторів, які надсилають інформацію про навколишнє середовище в центральну нервову систему. Процес організації, сортування та перероблення інформації, що надходить із органів чуття до центральної нервової системи, виступає принципом сенсорної інтеграції. Опрацювання сигналів, отриманих ЦНС, формує 
реакцію на ці сигнали і робить поведінку людини доцільною та раціональною.

Проте дедалі частіше фахівці стикаються із ситуацією, коли психофізичний розвиток дитини відстає від вікової норми. Збільшується кількість дітей зі складними комплексними порушеннями, які потребують тривалого корекційного та реабілітаційного втручання (Без'язична О. В., 2019, c. 26).

Ефективним засобом об'єднання інформації про навколишнє середовище, яка надходить до центральної нервової системи дитини, тобто сенсорної інтеграції, є застосування інтерактивної платформи Briolight, навчально-ігрові ефекти якої дозволяють створити індивідуальну траєкторію розвитку дитини, виступають інструментом корекційно-розвиткової роботи та вмотивовують дітей із особливостями психофізичного розвитку до опанування новими рухами, уміннями, навичками.

Аналіз основних досліджень із проблеми. Відповідно до статистики ВООЗ, яку наводять у своїх дослідженнях такі науковці, як: О. В. Без'язична, А. Б. Заплатинська, В. Ю. Мартинюк, протягом останніх років відбувається негативна тенденція щодо показників здоров'я дитячого населення: кількість здорових дітей зменшується, а, натомість, зростає кількість дітей 3 інвалідністю, з порушенням фізичного та розумового розвитку. Згідно зі статистикою ВОО3, це відбувається в усьому світі та становить близько 3-4 \% від загальної кількості дітей. Недоліки психофізичного розвитку спричиняють порушення отримання та опрацювання сигналів навколишнього середовища, які надходять до центральної нервової системи дитини, тобто порушення сенсорної інтеграції (Мартинюк В. Ю., 2019, c. 13).

Роль сенсорного розвитку дітей без патології досліджували науковці: А. Давидчук, 3. Ліштван, Л. Парамонова; із дітьми 3 порушенням розвитку - Н. Мінаєва, T. Обухова; рефлексотерапію в роботі 3 дітьми - Л. Бадалян, В. Козявкін; сенсорну депривацію, пов’язану із порушенням сенсорних відчуттів, - науковці: Г. Бєлова, О. Каліжнюк, І. Лєвченко, О. Мастюкова, Н. Сімонова, Т. Шамарін; сенсорну інтеграцію як метод корекції порушень мовленнєвого розвитку - Л. Л. Стахова, А. А. Душина; особливості побудови та використання ігрових застосунків у реабілітації - Дж. Бурке, М. МакНейл, Д. Чарльз, Л. Омеліна; специфіку діагностування стану сформованості сенсорної інтеграції дитини та іiї вплив на діяльність центральної нервової системи - Дж. Айрес, Ф. Лофорн, Л. Міллер. Так, за визначенням Дж. Айрес, засновниці теорії, сенсорна інтеграція - це впорядкування відчуттів, які надходять від різних аналізаторів до центральної нервової системи. Це несвідомий процес, що відбувається в головному мозку та організовує інформацію, яку сприйняли органи чуття. Сенсорна інтеграція наповнює змістом отримані відчуття, фільтрує їх, визначаючи, на чому треба зосередитися (наприклад, слухати вчителя) і формує свідому адекватну реакцію на ситуацію (Фаласеніді Т. М., Козак М. Я., 2017, с. 102; Стахова Л. Л., Душина А. А., 2019, с. 127).

Метою статті $\epsilon$ висвітлення застосування інструментів інтерактивної платформи Briolight як ефективного засобу гармонійного всебічного розвитку дитини, 3 одного боку, та потужного інструменту корекційно-розвиткового впливу на розвиток дитини з особливими освітніми потребами, 3 іншого.

Означена мета представлена такими завданнями:

- розкрити поняття сенсорної інтеграції та проблем, які викликає їі порушення;

- розглянути інструменти інтерактивної платформи Briolight як сучасного інструменту корекційно-розвиткової роботи з дітьми 3 ООП;

- наголосити на рівні професійної підготовки фахівців, які планують і реалізують корекційно-розвиткові заняття, щодо ефективного використання інтерактивного облад- 


\section{нання.}

Виклад основного матеріалу. Однією з головних проблем дитини з порушенням психофізичного розвитку, спричиненого органічними враженнями нервової системи, $€$ неспроможність інтегрувати сенсорну інформацію від органів чуття в цілісну картину їхнього реального оточення, що спричиняє викривлення сприйняття навколишнього середовища і неадекватну реакцію на нього. У дітей із порушенням сенсорної інтеграції спостерігаються погано розвинені ігрові, навчальні навички. Вони не можуть інтегрувати інформацію, що йде від очей і вух, рук і тіла, і тому не в змозі дати адаптивну відповідь на те, що чують або відчувають, пропускають деталі або не розуміють дій інших дітей. Іграшки, що вимагають навичок маніпуляції, можуть бути для них проблемою. Малюки ненавмисно ламають предмети або травмуються. Діти, які мають порушення сенсорної інтеграції, частіше відчувають стрес, оскільки для виконання завдань їм доводиться працювати більше, ніж їхнім одноліткам. Наприклад, гіперактивна дитина «стрибає по всьому класу» не тому, що цього хоче, а тому, що дезорганізація роботи центральної нервової системи не дає змоги зосередитися та утримувати увагу (Айрес Дж., 2009, c. 21-23).

Сенсорна інтеграція - це несвідомий процес, що відбувається в головному мозку, який організовує інформацію, яку сприйнято за допомогою органів чуттів (смак, вигляд, запах, дотик, звуки, рухи, вплив сили тяжіння, положення у просторі тощо); дозволяє свідомо діяти та реагувати на ситуацію; формує базу для теоретичного навчання й соціальної поведінки.

Сенсорна інтеграція є базовою основою для продуктивної та успішної діяльності школяра. Точність, координація, швидкість сенсомоторних реакцій $є$ показником зрілості мозкових структур. У разі порушення оброблення сенсорної інформації виникає шкільна неуспішність.

У своєму науковому дослідженні дисфункцію сенсорної інтеграції О. Кіпаренко обгрунтовано пов'язує із порушенням постави в дітей, функцій опорно рухового апарату, адже, відповідно до теорії функціональних систем, стабільність вертикальної позиції забезпечується через інтеграцію сигналів різних систем організму (зорової, вестибулярної, пропріоцептивної, тактильної тощо) (Кіпаренко О., 2020, с. 160-161).

Порушення сенсорної інтеграції обов'язково потребує корекції, оскільки у процесі розвитку дитини, який базується на сенсорному досвіді, має формуватися осмислена, доцільна поведінка, а згодом поступово опановуватися складніші види діяльності: від елементарних рухів - до навчання i творчості. Порушення оброблення сенсорної інформації на будь-якому 3 рівнів функціонування нервової системи негативно впливає на такі важливі сфери життя, як оволодіння руховими навичками, опанування емоціями, ігрову діяльність, регуляцію поведінки, навчання та соціальну взаємодію (Заплатинська А. Б., 2013, c. 51).

Вирішити це питання покликана концепція сенсорної інтеграції, заснована на збагаченні сенсорного досвіду. Корекційні заняття щодо збагачення такого досвіду базуються на залученні в роботу всіх аналізаторів: зорового, слухового, тактильного, нюхового, смакового, вестибулярного. Натомість активація мозку через стимуляцію первинних відчуттів набуває абілітаційного характеру (Сміян I. С., 2008).

Виникає закономірне питання: які інструменти, методи та прийоми має використовувати сучасний педагог нині, коли засоби віртуальної та доповненої реальності стали вже невід'ємною складовою нашого життя? Шукаючи відповідь на це запитання, рекомендуємо розглянути інтерактивну платформу Briolight як сучасний інструмент корекційно-розвиткової роботи, ефекти (ігри) якої дозволяють створити індивідуальну траєкторію розвитку дитини.

Інтерактивні ефекти (ігри) платформи Briolight умотивовують дітей із особливостями психофізичного розвитку до 
опанування новими рухами, уміннями, навичками, тобто до збагачення сенсорного досвіду. Усі вправи передбачають потужну сенсорну стимуляцію, що, так само, активізує цікавість та підвищує вмотивованість дітей. Так, наприклад, яскравий та динамічний ефект (гра «Кроти») інтерактивної підлоги спонукає дитину до рухової активності, активізує увагу, швидкість реакції, покращує зорово-моторну координацію. Додатковим сенсорним стимулом платформи є музичний або вербальний супровід вправ (Захарова Л. Г., 2020).

Нині велику кількість інклюзивно-ресурсних центрів, одним $з$ основних напрямів роботи яких є надання корекційно-розвиткових послуг, обладнано комплексом Briolight, що складається 3 таких інструментів:

- інтерактивна підлога та інтерактивна стіна 3 інтегрованою системою датчиків руху, які являють собою великі проєкційні екрани високої роздільної здатності, чутливі до переміщення та рухів уздовж поверхні підлоги та стіни;

- інтерактивна пісочниця - це прилад доповненої реальності, що створює чутливу до рухів людини проєкцію на реальний пісок;

- інтерактивна панель - рідкокристалічний екран високої роздільної здатності, що реагує на дотики;

- комплекс розвитку великої моторики - безконтактний сенсорний контролер $з$ екраном, що передає координати скелету людини до інтерактивного додатка, який представляє їх в ігровому вигляді. Система такого типу дає можливість користувачам керувати додатками за допомогою рухів рук, ніг та тулуба;

- комплекс розвитку дрібної моторики - модуль оптичного відстеження рухів, який із високою точністю фіксує координати рухів фаланг пальців та зап'ясть обох рук на відстані до 50 см від сенсору, розташованого на столі. Графічна реалізація на екрані «зчитаних» рухів дозволяє розвивати дрібну моторику. Наприклад, робота 3 віртуальним шматком глини, який обертається, або завдання обірвати пелюстки віртуальної квітки (Васильєв А. А., 2016, с. 79-80);

- інше обладнання, а саме: інтерактивне логопедичне дзеркало, інтерактивний метроном, інтерактивні гіроскопи тощо.

Використання інтерактивних ефектів у роботі з дітьми, які мають порушення психофізичного розвитку, значно збільшує ефективність корекційно-розвиткової роботи, оскільки діти додатково вмотивовані, перебуваючи безпосередньо «всередині ефекту» і самостійно створюючи певну реальність.

\section{боти.}

Результати експериментальної ро-

Як приклад розглянемо ігровий ефект «Морський бій» із розділу «Рухливість/релаксація». Цей ігровий ефект можна застосовувати як у горизонтальній (інтерактивна підлога), так й у вертикальній (інтерактивна стіна) площині з одним або декількома гравцями.

Умови гри, хід виконання. У проєкції в довільному режимі з'являються кораблі, що пливуть морем у різних напрямках. Завдання гравця/гравців - «поцілити» в якомога більшу кількість кораблів із гармат, розташованих з одного боку ігрового поля. Поцілити - означає здійснити рух у рамках дії датчиків руху, які відповідають за стрільбу в цій грі. Завдання для гравців ускладнюється тим, що гармати постійно рухаються, «вистежуючи» кораблі, які теж рухаються (курсують) в різних напрямках.

Говорячи про напрями корекційного спрямування названої інтерактивної гри, можемо зазначити такі:

- розвиток зорово-моторної координації;

- концентрація уваги;

- координація рухів;

- оволодіння/удосконалення довільними рухами верхніх/нижніх кінцівок (залежно від завдання педа- 
гога);

- орієнтування у просторі;

- перспективне планування дій;

- утримання рівноваги;

- налагодження соціальної взаємодіï;

- швидкість реакції.

Отже, ця інтерактивна гра може бути рекомендована до застосування дітям із: гіперактивністю; недостатньою соціальною взаємодією; нестійкістю уваги; порушенням координації; порушенням просторового праксису; порушенням функцій опорно-рухового апарату.

Говорячи про використання інтерактивного обладнання, зазначимо, що ефективність його застосування значною мірою залежить від професійної підготовки фахівця, який планує і реалізує корекційно-розвиткове заняття. Адже він має не тільки чітко уявляти рівень порушень розвитку дитини, але і володіти методикою використання вищезазначеного обладнання. Платформа дає широкі можливості педагогові не лише здійснювати корекцію розвитку дітей з ООП, а і вибудовувати індивідуальну освітню траєкторію дитини, оскільки перелік інструментів інтерактивної платформи включає: ефекти в розвитку рухових навичок; мови і мовлення; опанування академічними знаннями в тестових завданнях, дібраних відповідно до освітньої програми.

Навчання педагогічних працівників Миколаївської області послуговуватися інтерактивним обладнанням Briolight та застосовувати його в корекційно-реабілітаційних цілях здійснюється на базі обласного ресурсного центру з підтримки ін- клюзивної освіти Миколаївського ОІППО, де облаштовано тренувальні приміщення, обладнані інтерактивними інструментами. Здобуваючи освітні послуги на курсах підвищення кваліфікації, педагоги Миколаївщини мають змогу навчитися не лише послуговуватися цими інструментами, але й добирати ефекти відповідно до «дефіцитів» дитини, самостійно формувати теки із навчальними завданнями для кожної дитини, працювати 3 налаштуваннями системи.

Варто зазначити, що інтерактивне обладнання Briolight увійшло до «Типового переліку спеціальних засобів корекції психофізичного розвитку дітей з особливими освітніми потребами, які навчаються в інклюзивних та спеціальних групах закладів дошкільної освіти».

Висновки. У ході опрацювання питання корекції психофізичного розвитку дітей із особливими освітніми потребами засобами доповненої реальності розкрито поняття сенсорної інтеграції та проблем, які викликає іiі порушення; розглянуто інструменти інтерактивної платформи Briolight як сучасного інструменту корекційно-розвиткової роботи 3 дітьми з ООП; наголошено на рівні професійної підготовки фахівців, які планують і реалізують корекційно-розвиткові заняття з ефективного використання інтерактивного обладнання.

Перспективи наукових розвідок із цього напряму вбачаємо в поглибленому й докладному дослідженні ефективності застосування кожного окремого інструменту під час підвищення кваліфікації педагогічних працівників закладів освіти та інклюзивно-ресурсних центрів.

\section{ЛІТЕРАТУРА}

1. Айрес Э. Дж. Ребенок и сенсорная интеграция. Понимание скрытых проблем развития / Э. Дж. Айрес ; [пер. с англ. Юлии Даре]. - М. : Теревинф, 2009. - 272 с.

2. Без'язична О. В. Сенсорна інтеграція в реабілітації дітей з органічними ураженнями нервової системи / О. В. Без'язична / Збірник тез III міжнародної науково-практичної конференції «Сучасні питання фізичної реабілітації, рекреації та фізичного виховання різних груп населення». Том 3. м. Харків. - 2019. - № 1. - С. 26-29.

3. Васильєв А. А. Інтерактивні системи в соціальній реабілітації / А. А. Васильєв // Соціальна педіатрія та реабілітологія. - 2016. - № 8. - С. 79-80.

4. Заплатинська А. Б. Становлення поняття «сенсорна інтеграція» у корекційній педагогіці / А. Б. Заплатинська // Корекційна та соціальна педагогіка і психологія. - 2013. 
- Вип. 23 (1). - С. 48-57.

5. Захарова Л. Г. Технології використання інноваційного інтерактивного обладнання в корекційно-розвитковій діяльності в умовах інклюзивно-ресурсних центрів : методичні рекомендації для фахівців ІРЦ та установ з інклюзивною формою навчання / Л. Г. Захарова, Г. Л. Норд. - Миколаїв : Вид-во ЧНУ ім. Петра Могили, 2020. - 108 с.

6. Кіпаренко О. Сенсорна інтеграція як метод корекції розладів у дітей / О. Кіпаренко // Проблеми сучасної психології. Том 49. Одеса, 2020. C. 152-176. DOI: https://doi. org/10.32626/2227-6246.2020-49

7. Мартинюк В. Ю. Концептуальні засади допомоги дітям з обмеженням життєдіяльності /В. Ю. Мартинюк // Оригінальні дослідження. Міжнародний неврологічний журнал. № 1 (103), Київ, 2019 р. - C. 6-16. DOI : 10.22141/2224-0713.1.103.2019.158633

8. Реабілітація дітей раннього віку з ураженням нервової системи - запорука їх соціальної адаптації / І. С. Сміян, Г. А. Павлишин, Г. І. Корицький, Н. М. Свірська, А. О. Сковронська, Е. В. Стеценко // Медична гідрологія та реабілітація. - 2008. - Т. 6. № 1. - C. 14- 20 .

9. Стахова Л. Л., Душина А. А. Сенсорна інтеграція як метод корекції порушень мовленнєвого розвитку дітей дошкільного віку /Л. Л. Стахова, А. А. Душина. Сучасні проблеми логопедії та реабілітації. - Суми. - 2019. - С. 127-129.

10. Фаласеніді Т. М., Козак М. Я. Порушення сенсорної інтеграції у дітей з особливими потребами / Т. М. Фаласеніді, М. Я Козак // «Молодий вчений». 2017. - № 9 (49). - C. 102-104.

11. Omelina L., Jansen B., Bonnechère B., Van Sint S., Cornelis J. J. Serious games for physical rehabilitation: designing highly configurable and adaptable games // Proc. 9th Intl Conf. Disability, Virtual Reality \& Associated Technologies, Laval, France, 10-12 Sept. 2012. Режим доступу: http://www.icdvrat.reading.ac.uk/2012/papers/ICDVRAT2012_S06N5_ Omelina_etal.pdf

\title{
КОРРЕКЦИЯ ПСИХОФИЗИЧЕСКОГО РАЗВИТИЯ ДЕТЕЙ С ОСОБЫМИ ОБРАЗОВАТЕЛЬНЫМИ ПОТРЕБНОСТЯМИ ИНСТРУМЕНТАМИ ВИРТУАЛЬНОЙ РЕАЛЬНОСТИ ИНТЕРАКТИВНОЙ ПЛАТФОРМЫ ВRIOLIGHT
}

\author{
Бавольская Оксана, \\ доктор философии в области образования, \\ методист областного ресурсного ичентра \\ по поддержке инклюзивного образования \\ Николаевский областной институт \\ последипломного педагогического образования \\ ул. Наваринскал, 6, 56001, г. Николаев, Украина \\ oksana.bavolska@moippo.mk.ua
}

Васильєв Андрей, кандидат экономических наук, доиент Черноморского национального университета имени Петра Могиль, основатель Briolight ул. 68 Десантников, 10, 54000, г. Николаев, Украина brio@briolight.com

В статье рассмотрены инструменты интерактивной платформы Briolight как эффективного средства коррекции нарушений психофизического развития детей с осо- 
быми образовательными потребностями. Применение данных интерактивных инструментов основывается на положениях комплексного привлечения ведущих анализаторов, позволяет «оживить» учебно-коррекционный материал и способствует успешному усвоению информащии.

Определены основные характеристики инструментов и содержание указанной технологии. Раскрыты особенности использования таких инструментов интерактивной платформы Briolight: интерактивный пол, интерактивная стена, интерактивная песочница, интерактивная панель, комплекс развития крупной моторики, комплекс развития мелкой моторики, интерактивное логопедическое зеркало, интерактивный метроном, интерактивные гироскопьы.

Обоснована целесообразность применения инструментов интерактивной платформы Briolight в коррекционно-развивающей работе с детьми, имеющими нарушения психофизического развития. Определены функиии педагога, который применяет данную технологию в коррекиионно-развивающей работе.

Определены перспективы в углубленном и подробном исследовании эффективности применения данного инструмента при повышении квалификации педагогических работников учреждений образования и инклюзивно-ресурсных изентров.

Ключевые слова: дети с особыми образовательными потребностями; интерактивная платформа Briolight; коррекция развития; сенсорная интеграџия.

\title{
CORRECTION OF PSYCHOPHYSICAL DEVELOPMENT OF CHILDREN WITH SPECIAL EDUCATIONAL NEEDS BY VIRTUAL REALITY MEANS OF BRIOLIGHT INTERACTIVE PLATORM
}

\author{
Bavolska Oksana, \\ Doctor of Philosophy in Education, \\ Methodist of the regional resource center to support inclusive education \\ Mykolaiv In-Service Teachers Training Institute \\ 4-a Admiralska Street, 54001, Mykolaiv, Ukraine \\ oksana.bavolska@moippo.mk.ua \\ Vasyliev Andrei, \\ founder of Briolight, Associate Professor at Petro Mohyla \\ Black Sea National University \\ 10 Street 68 Desantnikiv, 54000, Mykolaiv, Ukraine \\ brio@briolight.com
}

The article highlights the use of tools of the interactive platform Briolight as an effective means of correction of disorders of psychophysical development of children with special educational needs. The use of interactive Briolight tools is based on the provisions of complex involvement of leading analyzers, which allows to «revive» the training and correction material, and contributes to the successful assimilation of information.

The main characteristics of the tools and the content of the specified technology are determined. The peculiarities of using the following tools of the Briolight interactive platform are revealed: interactive floor, interactive wall, interactive sandbox, interactive panel, large motility correction complex, fine motility correction complex, interactive speech therapy mirror, interactive metronome, interactive gyroscopes, etc. 
Emphasis is placed on the appropriateness of using the tools of the interactive platform Briolight in correctional and developmental work with children with mental and physical disabilities. The functions of the teacher who uses this technology in correctional and developmental work are determined.

Prospects in the in-depth and detailed study of the effectiveness of this tool in the training of teachers of educational institutions and inclusive resource centers are identified.

The key condition for the harmonious all-round development of a child is his full-fledged sensory development. That is, the development of processes of perception and formation of ideas about objects and phenomena of the world. These processes occur due to the work of analyzers, which send information about the environment to the central nervous system. The process of organizing, sorting and processing information coming from the senses to the central nervous system is the principle of sensory integration. Processing of signals received by the CNS, forms a response to these signals and makes human behavior appropriate and rational.

However, more and more often specialists are faced with a situation when the psychophysical development of a child does not meet the age norm.

The Briolight platform is a tool for correctional and developmental work, the effects of which allow you to create an individual trajectory of child development. Interactive games of the Briolight platform motivate children with special needs to master new movements, skills, abilities.

Keywords: Briolight interactive platform; children with special educational needs; development correction; sensory integration.

\section{REFERENCES}

1. Ajres, Je. Dzh. (2009). Rebenok i sensornaja integracija. Ponimanie skrytyh problem razvitija [Child and sensory integration. Understanding hidden developmental issues]. Terevinf (rus).

2. Beziazychna, O. V. (2019). Sensorna intehratsiia v reabilitatsii ditei z orhanichnymy urazhenniamy nervovoi systemy. [Sensory integration in the rehabilitation of children with organic lesions of the nervous system]. Zbirnyk tez III mizhnarodnoi naukovo-praktychnoi konferentsii «Suchasni pytannia fizychnoi reabilitatsii, rekreatsii ta fizychnoho vykhovannia riznykh hrup naselennia». T. 3. 1, 26-29. Kharkiv (ukr).

3. Falasenidi, T. M. \& Kozak, M. Ya. (2017). Porushennia sensornoi intehratsii u ditei $\mathrm{z}$ osoblyvymy potrebamy [Disorders of sensory integration in children with special needs]. Molodyi vchenyi, 9, 102-104 (ukr).

4. Kiparenko, O. (2020). Sensorna intehratsiia yak metod korektsii rozladiv u ditei [Sensory integration as a method of correction of disorders in children]. Problemy suchasnoi psykholohii, 49, 152-176. Odesa (ukr).

5. Martyniuk, V. (2019). Kontseptualni zasady dopomohy ditiam z obmezhenniam zhyttiediialnosti [Conceptual principles of helping children with disabilities]. Mizhnarodnyi nevrolohichnyi zhurnal, 1 (103), 6-16. Kyiv (ukr).

6. Omelina, L., Jansen, B., Bonnechère, B., Van Sint, S., Cornelis, J. J. Serious games for physical rehabilitation: designing highly configurable and adaptable games // Proc. 9th Intl Conf. Disability, Virtual Reality \& Associated Technologies, Laval, France, 10-12 Sept. 2012. Online source: http://www.icdvrat.reading.ac.uk/2012/papers/ICDVRAT2012_S06N5 Omelina_etal.pdf(eng).

7. Smiian, I. S., Pavlyshyn, H. A., Korytskyi, H. I. \& et al. (2008). Reabilitatsiia ditei 
rannoho viku z urazhenniam nervovoi systemy - zaporuka yikh sotsialnoi adaptatsii. Medychna hidrolohiia ta reabilitatsiia [Rehabilitation of young children with lesions of the nervous system - the key to their social adaptation. Medical hydrology and rehabilitation]. Kyiv (ukr).

8. Stakhova, L. \& Dushyna, A. (2019). Sensorna intehratsiia yak metod korektsii porushen movlennievoho rozvytku ditei doshkilnoho viku [Sensory integration as a method of correction of speech disorders in preschool children]. Suchasni problemy lohopedii ta reabilitatsii, 127129. Sumy (ukr).

9. Vasyliev, A. A. (2016). Interaktyvni systemy v sotsialnii reabilitatsii [Interactive systems in social rehabilitation]. Sotsialna pediatriia ta reabilitolohiia,79-80. Kyiv (ukr).

10. Zakharova, L. H. \& Nord, H. L. (2020). Tekhnolohii vykorystannia inovatsiinoho interaktyvnoho obladnannia $v$ korektsiino-rozvytkovii diialnosti $v$ umovakh inkliuzyvnoresursnykh tsentriv [Technologies of using innovative interactive equipment in correctional and developmental activities in the conditions of inclusive resource centers]. Mykolaiv: Vyd-vo ChNU im. Petra Mohyly (ukr).

11. Zaplatynska, A. B. (2013). Stanovlennia poniattia «sensorna intehratsiia» u korektsiinii pedahohitsi [Formation of the concept of «sensory integration» in correctional pedagogy]. Korektsiina ta sotsialna pedahohika i psykholohiia, vyp. 23 (1), 48-57. Kyiv (ukr). 